\title{
Abdelaziz Bennis, Carnet bibliographique André Malraux, Critique, 1990-2002
}

\section{Emanuele Kanceff}

\section{(2) OpenEdition}

\section{Edizione digitale}

URL: http://journals.openedition.org/studifrancesi/33622

DOI: 10.4000/studifrancesi.33622

ISSN: 2421-5856

\section{Editore}

Rosenberg \& Sellier

\section{Edizione cartacea}

Data di pubblicazione: 1 décembre 2005

Paginazione: 675-676

ISSN: 0039-2944

\section{Notizia bibliografica digitale}

Emanuele Kanceff, «Abdelaziz Bennis, Carnet bibliographique André Malraux, Critique, 1990-2002», Studi Francesi [Online], 147 (XLX | III) | 2005, online dal 30 novembre 2015, consultato il 20 avril 2021. URL: http://journals.openedition.org/studifrancesi/33622; DOI: https://doi.org/10.4000/studifrancesi. 33622

Questo documento è stato generato automaticamente il 20 avril 2021.

\section{(c) $(1) \ominus$}

Studi Francesi è distribuita con Licenza Creative Commons Attribuzione - Non commerciale - Non opere derivate 4.0 Internazionale. 


\title{
Abdelaziz Bennis, Carnet bibliographique André Malraux, Critique, 1990-2002
}

\author{
Emanuele Kanceff
}

\section{NOTIZIA}

ABDELAZIZ BENNIS, Carnet bibliographique André Malraux, Critique, 1990-2002, 1 [1990-1996], Paris-Caen, Lettres Modernes Minard, 2004, n. p. («La Revue des Lettres Modernes»Les Carnets bibliographiques).

1 La bibliografia malruciana, anche per quanto concerne il campo della critica, non è alle sue prime armi. Nel 1972 Walter G. Langlois aveva pubblicato presso le Lettres Modernes un "calepin" della serie allora in voga, che copriva quarantasei anni di carriera letteraria di Malraux (1924-1970) visti dalla critica in lingua inglese, recensendo 1268 titoli. Intanto Peter C. Hoy pubblicava, presso lo stesso editore, una numerosa serie di carnets bibliographiques nella «Revue des lettres modernes». In seguito alla maggiore produzione critica degli anni seguenti, John B. Romeiser ripubblicava nel 1994 una bibliografia analitica: André Malraux. A Reference Guide, 1940-1990, che costituiva un aggiornamento importante su mezzo secolo di critica. Tuttavia, rimaneva scoperto fino ad oggi il periodo successivo, importante se non altro per le conseguenze dell'ascesa delle ceneri di Malraux al Panteon e per la pubblicazione, nello stesso 1996, del II e III tomo delle sue CEuvres complètes nella "Bibliothèque de la Pléiade". La doppia ricorrenza del centenario della sua nascita e del venticinquennale della sua scomparsa costituiscono, nel 2001, un'altra grande occasione di scrittura critica, cui corrispondono circa seicento titoli nella presente bibliografia, su un totale di poco più di 3600 referenze.

2 Il presnte volume è corredato di un indice degli autori e di un indice delle pubblicazioni. È organizzato per anno, all'interno per alfabeto; gli articoli anonimi 
figurano in testa di ciascun anno, in ordine alfabetico per titolo dei periodici in cui sono pubblicati. Un circolino all'inizio delle notizie segnala le opere dedicate interamente a Malraux. I volumi collettivi e i numeri speciali di periodici sono segnalati secondo l'ordine alfabetico del titolo, con rinvio, nello stesso anno, ai nomi dei collaboratori. 